EMBRYRIDDLE

SCHOLARLY COMMONS
Journal of Aviation/Aerospace

Education \& Research

Volume 16

Number 2 JAAER Winter 2007

Article 1

Winter 2007

\title{
A Delphi Study: Expanding K-12 Student Knowledge and Interests in Aviation/Aerospace Recommendations from NASA Aerospace Education Specialists
}

Dovie M. Brown

Mary N. Kutz

Timm Bliss

timm.bliss@okstate.edu

Follow this and additional works at: https://commons.erau.edu/jaaer

\section{Scholarly Commons Citation}

Brown, D. M., Kutz, M. N., \& Bliss, T. (2007). A Delphi Study: Expanding K-12 Student Knowledge and Interests in Aviation/Aerospace Recommendations from NASA Aerospace Education Specialists. Journal of Aviation/Aerospace Education \& Research, 16(2). https://doi.org/10.15394/jaaer.2007.1470

This Article is brought to you for free and open access by the Journals at Scholarly Commons. It has been accepted for inclusion in Journal of Aviation/Aerospace Education \& Research by an authorized administrator of Scholarly Commons. For more information, please contact commons@erau.edu. 


\section{A DELPHI STUDY: EXPANDING K-12 STUDENT KNOWLEDGE AND INTEREST IN AVIATION/AEROSPACE Recommendations from NASA Aerospace Education Specialists}

Dovię M. Brown, Mary N. Kutz, \& Timm Bliss

\section{INTRODUCTION AND BACKGROUND}

An aging aerospace workforce coupled with declining student interest and skills beginning at the secondary level and running through the doctoral level has prompted a potential crisis in the aviation/aerospace industry. The Bureau of Labor Statistics estimated that 54 percent of U.S. aerospace workers over age 45 will leave the field by 2008 opening up some six million aerospace jobs. If the existing trends continue, there will not be enough workers to fill those positions which are vital to the U.S. economy and security. Aerospace employment is at its lowest in 50 years (Aerospace Industries Association, 2004).

Data from the Commission on the Future of the U.S. Aerospace Industry indicated that math and science performance of U.S. high school seniors ranks near the bottom internationally (2002). The Commission made the following recommendation:

The Commission recommends the nation immediately reverse the decline in, and promote the growth of, a scientifically and technologically trained U.S. aerospace workforce. In addition, the nation must address the failure of the math, science and technology education of Americans. The breakdown of America's intellectual and industrial capacity is a threat to national security and our capability to continue as a world leader (p. xvi).

The Commission further stressed the importance of taking action to improve math and science instruction across the entire education range- $\mathrm{K}-12$ through graduate school. In an effort to encourage students to pursue scientific interests in aviation/aerospace, Aerospace Education Specialists working for the National Aeronautics and Space Administration (NASA) are involved in a relatively new effort to work with K-12 educators to provide in-classroom education about the field of aviation/aerospace. As former K-12 educators, these specialists are constantly looking for new and creative ways to convey to current K-12 educators the importance of aviation/aerospace careers to the future of the industry. And, as representatives of NASA, these specialists are trained and experienced in matching agency resources with the needs of educators.

\section{Problem and Purpose of the Study}

The purpose of this study was to obtain the most important recommendations of NASA Aerospace Education Specialists regarding how to expand student knowledge and interest in aviation/aerospace during the next five years. The authors of this article who facilitated the Delphi study included two associate professors and a doctoral candidate at Oklahoma State University. The objective of the study was to obtain recommendations of 15 NASA Education Specialists regarding their perspectives on issues for consideration in developing future aviation/aerospace education programs in the K-12 curriculum.

The Delphi Method

The Delphi method was originally developed and refined by the Rand Corporation in the 1950s and 1960 s for the U.S. government as a technique to help the military reach consensus pertaining to long-term strategies of national defense. Since that time, the Delphi method has gained wide acceptance as a preferred means of eliciting and refining the opinions of a homogeneous panel of experts. 
Ausburn (2002) stated that "The technique uses a panel of experts and a facilitator to obtain, distill, and converge multiple inputs on a designated question or issue" (p. 84). Typically, in Delphi studies, the selection of a panel of experts is purposive in that the selection is based on the supposed knowledge or expertise of those participating in the study. In this study, the panel of NASA Aerospace Education Specialists consisted of former educators with a minimum of five years experience in the K-12 environment. There experience met the requirements of the Delphi method in that the participants have knowledge about specific recommendations for expanding student interest and participation in the field of aviation/aerospace over the next five years.

One of the major strengths of the Delphi is that the guarantee of anonymity provides an open forum where participants are more willing to share information and perspective more honestly. This is accomplished through a series of input rounds and controlled feedback. Input from each round is collected, analyzed, and synthesized by the facilitators/researchers and subsequently provided as anonymous feedback to the panelists. Over the course of the rounds, the opinions of the panelists begin to come together to reflect a consensus of views. Generally after three to four rounds, a clear depiction of the group's views is evident (Lindstone \& Turoff, 1975; Martino, 1972).

\section{The NASA Delphi Study}

The panel of experts in the study was a cohort of NASA doctoral students enrolled in the $\mathrm{PhD}$ program at Oklahoma State University in Environmental Sciences and who attended the Seminar in Aerospace Education Leadership and Management during the spring 2004 semester. Consenting participants held positions as NASA Aerospace Education Specialists working with K-12 educators to assist them in using instructional methods that will increase student interest in and desire to pursue aviation/aerospace as a vocation. All specialists were experienced professional educators. As Aerospace Education Specialists the participants conduct workshops, symposiums and assist K-12 educators with development of their aerospace curricula. Although the population of this group was limited, their daily exposure to the concerns and recommendations of a variety of educators throughout the
United States offered a rich source of data for Delphi input on topics related to K-12 education.

Fourteen Educational Specialists enrolled as students in the leadership class chose to participate on the panel, representing a participation rate of $93.3 \%$. All fourteen panelists participated in all three input rounds for a $100 \%$ participation rate in the study.

All three rounds of the Delphi were conducted via the Internet. After each round, data were analyzed both qualitatively and quantitatively. A qualitative analysis of the content was performed and responses were coded into categories. Quantitative analysis was completed by the facilitators/researchers through descriptive statistics such as response frequencies, rank ordering, and summation rank.

In round one, each panelist was asked to list the five most important recommendations he or she would make to K-12 educators in regard to expanding student knowledge and interest in aviation/aerospace during the next five years. Upon receipt of the first round input from the panelists $(n=14)$, the facilitators analyzed the content of the responses for similar themes and a statement or recommendation was written for each theme identified. A combination feedback form from round one and input form for round two was then provided to the panelists with an unranked set of 31 statements derived from the thematic analysis of round one input. Panelists were asked to analyze and evaluate the recommendations from round one and to rank order them in descending order, with the first choice listed as rank one and the tenth choice as rank ten. The rank points earned by each statement were summed to compute a score called "sigma rank points" or $\Sigma$ RankPoint.

In round three, the panelists were asked to review the feedback from round two and to rate and rank their top five responses in descending order, with the first choice listed as rank one and the fifth choice as rank five. As is often the case in Delphi studies, a convergence of opinion began to take place as early as round two. In this study, four of the five top ranked recommendations (numbers 1, 2, 3 and 5) in round three were also in the top five recommendations in round two. The final results were presented to the panelists along with the $\Sigma$ RankPoint for each statement. 
Top Ranked Recommendations from NASA Aerospace Education Specialists $(N=14)$

\begin{tabular}{llll} 
Item $\quad$ SRankPoint Frequency $\quad$ Final Rank \\
\hline
\end{tabular}

Make solid connections with other subjects

43

28

life examples

Find and establish collaborations with other groups with similar goals

Take advantage of personal professional development

Encourage schools to participate in opportunities offered by NASA and others
23

17

14
8

7

8

3

4

5

\section{Panelists Recommendations}

Recommendations 1 and 2:

The recommendations that received the top rankings, one and two respectively, dealt with the suggestion that K-12 educators make solid connections with other subjects such as mathematics, science and technology in such a way that they foster interest and excitement in understanding their relevance to aerospace and aviation $(f=43)$. This was further elaborated in the recommendation that educators provide students real world/real life examples for concepts being taught by including current events such as shuttle launches, discoveries, and improvements in flight, passenger safety, and efficiency $(f=28)$.

These two recommendations appears consistent with the current philosophy in education that supports the notion that students learn more effectively when teaching is offered in context and that "learning to know" should not be separated from "learning to do" (Wonacott, 1992). The Secretary's Commission on Achieving Necessary Skills (SCANS) report (1991) embraces the concept of infusing the skills and knowledge needed in the $21^{\text {* }}$ Century workplace into the curriculum. Also, students can take knowledge learned in one area and apply it to another area. This enables them to see the relevance of learning a particular subject, such as math or science, and how the knowledge gained can create a direct link to other areas of interest.
Ascher \& Flaxman (1993) found that many studies indicate that it is generally easier to learn abstract or theoretical concepts under contextualized or applied conditions. This may be accomplished in a variety of ways including through individual courses, course clusters, career academies or today's magnet school concept.

Creative contextualized instruction in aviation and space can be as simple as two or more teachers collaborating to make connections between their subjects to use a teamteaching approach or organizing curricula around a cluster that focuses on related occupations. It may be as complex and sophisticated as the recently established one-of a kind aviation institute in partnership with and located within the Choctawhatchee High School in Fort Walton Beach, Florida where instructors from Embry-Riddle Aeronautical University (ERAU) will teach several of the same courses offered at the university's campuses and offer three tracks leading to degree programs at ERAU in Aviation, Aviation Maintenance Technology and Flight. Students who take courses at the Aviation Institute can earn up to 27 credits transferable to ERAU (ERAU, 2004).

Magnet schools, organized around broad themes on a school-wide basis rather than a school within a school concept, provide an even more complex and comprehensive option for making connections and incorporating broad themes into the curriculum. The Addison Aerospace and 
Science Magnet School, in Roanoke, Virginia, is an example of a middle school offering students opportunity to learn in a simulated NASA control room how to plan and coordinate functions related to launch of a space vehicle and other activities related to careers in aeronautics (Finch, Frantz, Mooney, \& Aneke, 1997).

Recommendation 3:

The third highest ranking recommendation by the panelists concerned the need for community involvement in helping to prepare students for the complex and rapidly changing workplace. It was recommended that educators find and establish collaborations, with civic/community groups that have similar goals to help generate interest, funds, and experiences and to obtain speakers, experts, and programs at little to no cost $(f=23)$. Such organizations as Civil Air Patrol, National Air Guard groups, private flight clubs, NASA centers, science museums, and airports were mentioned as a few of the possibilities. Enlisting the involvement of other community organizations increases the potential to maintain the vitality of existing programs and provides opportunities to connect what is leamed in the classroom to the "real world." These collaborative efforts can also help students develop required skills by matching the needs of the work world through relevant curriculum and opportunities to shape their life careers (Lankard-Brown, 1996).

One of the primary concepts in the notion of contextualized learning involves the development of instruction that situates learning in a specific context and provides opportunities for authentic practice (Stasz, Ramsey, Eden, DaVanzo, Farris \& Lewis, 1993). Community, business, and industry relationships must be developed to prepare students for employment or advanced study in a specific career field (Finch, et al, 1997).

Recommendation 4:

The current thinking about the significance of professional development among educators was evident in the fourth and fifth ranking recommendations. The panelists proposed that educators take advantage of as many personal professional development opportunities as possible to stay current, gain insight, and network $(f=17)$. These opportunities included visiting facilities, joining professional organizations, reading professional journals, staying up to date on current trends, and attending conferences and workshops.

Significant attention has been placed on professional development initiatives as a result of the passage of the No Child Left Behind (NCLB) Act of 2001. Although current NCLB mandates call for increased investment in professional development activities, funding is not always available. Many educators are actively seeking out partnerships with business, civic, and government organizations as a means to expand professional development opportunities. One of the guiding principles for consideration in designing and implementing an effective professional development program is to ensure community involvement and support for professional development initiatives (Cocoran, 1995; Peredo, 2000; Wilde, 1996; Feist, 2003).

Teachers must maintain current knowledge of the aerospace workplace. This will require assistance not only from their school administrators but from community and industry leaders in job shadowing, internships, workshops, and other activities related to the field. Summer university workshops and academies for teachers are an additional source of current and relevant industry-specific data.

\section{Recommendation 5:}

The fifth ranked recommendation was for NASA Aerospace Education Specialists to more actively encourage schools to take advantage of opportunities offered by NASA and other organizations $(f=14)$. For example, opportunities exist for K-12 educators to participate in NASA sponsored activities such as design challenges, International Space Station Live events, EarthKam, NASA Educator Astronaut Program, NASA Explorer Schools, and NASA Explorer Institutes. These programs are specifically designed to stimulate student, educator, and public interest in science, technology, engineering, and mathematics through NASAsponsored educational opportunities. Many projects combine multiple curriculum areas into one unique project thus exposing students to various career possibilities and activities related to NASA's Vision for Space Exploration. NASA Aerospace Education Specialists are in a unique position to be directly involved in promoting space and science on a national scale.

\section{Conclusions and Recommendations}

The NASA Aerospace Education Specialists who participated in the Delphi study offered a rich source of data for addressing the concerns of the aviation/aerospace industry due to their continual exposure to student and educator needs across the country. Their input reflects their perception of the urgency of identifying relevant contexts for students in understanding new information in this field. Their input also addressed the challenging nature of the task ahead in organizing information in meaningful ways for advancing student understanding of math, science, and a multitude of other interdisciplinary skills that the aerospace industry requires. Whether student needs are addressed by 
creative teaching in a contextual environment or by a specialized academy or school aimed at comprehensive learning and career progression, this study emphasized the importance of a close association between the aviation and space industry and academia to create an environment open to experimentation, exploration and change.

Although the findings of this study were limited to the experiences of a small population of aerospace educators, they appear to be consistent with much of the literature related to education in general. The findings simply highlighted the perceptions of educators related to a need for contextual learning, community involvement and professional development/partnerships supported by the necessary resources and funding for innovative teaching approaches and curriculum change.

Dovie (Dee) Brown is a graduate student in the College of Education, Oklahoma State University, Stillwater, Oklahoma, and is currently completing her dissertation toward a doctorate in Occupational Education Studies. She holds a Masters of Science in Natural and Applied Sciences, aviation and space option, from Oklahoma State University and a Bachelor of Business Administration degree from the University of Central Oklahoma. Her experience includes 23 years with the Department of Defense (DOD) and the Federal Aviation Administration (FAA).

Dr. Mary Kutz is an associate professor and aviation education (AVED) graduate coordinator in the College of Education, Aviation and Space Education, Oklahoma State University, Stillwater, Oklahoma. Her experience with aviation management and leadership includes 20 years with the Federal Aviation Administration (FAA) in a variety of leadership roles including that of Manager of the Airmen Certification Branch with responsibility for certification of all U.S. civil airmen. Her FAA experience also included responsibility for counseling managers on performance issues and conducting management/supervisory training for the FAA Mike Monroney Aeronautical Center's Human Resource Management Division. Dr. Kutz holds a Doctor of Education degree in Applied Educational Studies, Aviation and Space Education, Oklahoma State University, as well as a Masters of Business Administration and a Bachelors of Business Administration degree from the University of Central Oklahoma.

Timm Bliss is a program coordinator and assistant professor in aviation education, Oklahoma State University. Dr. Bliss is currently in his $6^{\text {th }}$ year as a faculty member at OSU. Dr. Bliss has developed and instructed the following undergraduate and graduate courses during his tenure at OSU: Aviation Finance, Aviation Marketing, The Air Carrier Industry, Airport Planning and Management, History of Aviation, Airline Economics, Current Issues in the Airline Industry, and Guided Readings and Research in Aviation. Dr. Bliss has peer-reviewed scholarly publications in the following academic journals; the International Journal of Applied Aviation Studies; the Collegiate Aviation Review; and the Journal of In-Service Education. He has presented his scholarly work several times at international, national and state academic and professional conferences including: the International Conference on College Teaching and Learning; the University Aviation Association Fall Education Conference; and the Oklahoma Aviation Education Research Symposium. 


\section{REFERENCES}

Aerospace Industries Association (2004). Revitalization of the aerospace workforce. Retrieved September 5, 2004, from http:/www,aia-aerospace.org/issues/subject/employment facts.cfm

Ascher, C., \& Flaxman, E. (1993. A time for questions: The future of integration and tech prop. New York: Institute on Education and the Economy, Teachers College, Columbia University.

Ausburn, L. (2003). Beyond the inflection point: The softer side of learning's new digital landscape. Scholary Practitioner Quarterly, 2(1), 79-97.

Commission on the Future of the U.S. Aerospace Industry (2002). Retrieved September 5, 2004, from http://www.ita.doc/gov/td/2erospace/aerospacecomission/AeroCommissionFinal Report.pdf

Corcoran. T. (1995). Helping teachers teach well: Transforming professional development. Consortium for Policy Research in Education (CPRE) Briefs. Retrieved September 15, 2002, from http://www.ed.gov/pubs/CPRE/t61/

Embry-Riddle Aeronautical University (ERAU) (2004). Retrieved September 5, 2004, from http:/www.erau.edu/er/newsmedia/newsreleases/2004/institute.html

Feist. L. (2003). Removing barriers to professional development. T.H.E. Journal. (June/2003), 30(11), 30.Finch, C., Frantz, N., Mooney, M., \& Aneke, N. (1997). Designing the thematic curriculum: An all aspects approach (MDS-956). Virginia Polytechnic Institute and State University.

Finch, C., Frantz, N., Mooney, M., \& Aneke, N. (1997). Designing the thematic curriculum: An all aspects approach (MDS956). Virginia Polytechnic Institute and State University.

Lankard-Brown, B. (1996). Community involvement in K-12 career education. (ERIC Clearinghouse on Adult, Career \& Vocational Education, Information Series No. 177).

Lindstone, H.A., \& Turoff, M. (Eds). (1975). The Delphi method: Techniques and applications. Sydney, Australia: Addison-Wesley.

Martino, J.P. (1972). Technological forecasting for decision-making. New York: American Elsevier Publishing Company.

No Child Left Behind Act of 2001. U.S. Department of Education.

Peredo, M. (2000). Directions in professional development. National Clearinghouse for Bilingual Education. Retrieved September 15, 2002, from http://www.ncela.gwu.edu/ncbepubs/reports/directions/index.htm

Secretary's Commission on Achieving Necessary Skills (SCANS) Report (1991). What Work Requires of Schools: A SCANS Report for America 2000.

Stasz, C., Ramsey, K., Eden, R., DaVanzo, J., Farris, H., \& Lewis, M. (1993). Classrooms that work: Teaching generic skills in academic and vocational settings. Santa Monica, CA: Rand.

Wilde, J. (1996). Assessment strategies for professional development activities. Retrieved September 15, 2002, from http://www.ncela.gwu.edu/miscpubs/eacwest/profdev/index.htm

Wonacott, M.E. (1992). Career education and applied academics. Columbus, OH: The Ohio State University. (ERIC Clearinghouse on Adult, Career, \& Vocational Education, Information Series No. 128). 